\title{
UMOWA O DOŻYWOCIE W SFERZE WSPÓLNOŚCI MAJĄTKOWEJ MAŁŻEŃSKIEJ*
}

\author{
UWAGI WSTĘPNE
}

Normatywny model umowy o dożywocie stanowi oryginalny rys polskiego ustawodawstwa na tle innych, zagranicznych regulacji prawnych. W obecnych stosunkach społecznych umowa o dożywocie ma znaczenie nie tylko w obrocie gospodarstwami rolnymi, ale także w stosunkach pozawiejskich, stanowiąc formę „zabezpieczenia” na późne lata starości lub też na wypadek niezdolności do pracy. W obrocie prawnym dostrzegalna jest tendencja wzrostowa liczby zawieranych umów o dożywocie, w tym przede wszystkim coraz większa liczba umów, której przedmiotem są nieruchomości nierolnicze. Stanowi to potwierdzenie, że umowa o dożywocie jest ważnym i pożytecznym instrumentem prawnym, będącym obecnie w fazie rozwoju stosunków społeczno-gospodarczych. Potrzeba pogłębionych badań i uporządkowania kluczowych zagadnień związanych ze stosunkiem prawnym wynikającym $\mathrm{z}$ umowy o dożywocie wynika w główniej mierze z aktualnych potrzeb społecznych nakierunkowanych na poszukiwanie alternatywnych sposobów zabezpieczenia interesów majątkowo-osobistych osób starszych, których udział w społeczeństwie wzrasta $\mathrm{z}$ roku na rok ${ }^{1}$.

Mgr Adriana TomczyK - asystent w Instytucie Nauk Prawnych, Wydział Prawa i Administracji, Uniwersytet Szczeciński, ul. Narutowicza 17A, 70-240 Szczecin, e-mail: adriana.tomczyk@usz.edu. pl; https://orcid.org/0000-0002-2467-980X

* Badania w tym zakresie powiązane są z analizami składającymi się na rozprawę doktorską poświęconą problematyce skutków cywilnoprawnych naruszenia norm moralnych między osobami bliskimi.

${ }^{1}$ Sytuacja demograficzna osób starszych i konsekwencje starzenia się ludności Polski w świetle prognozy na lata 2014-2050, Warszawa: Główny Urząd Statystyczny 2014, [w:] https:// stat.gov.pl/obszary-tematyczne/ludnosc/ludnosc/sytuacja-demograficzna-osob-starszych-i-konsek wencje-starzenia-sie-ludnosci-polski-w-swietle-prognozy-na-lata-2014-2050,18,1.html [dostęp: 5.06.2019], s. 34 . 
Jednym z ważkich praktycznie i skomplikowanych teoretycznie zagadnień jest wpływ reguł wspólności majątkowej małżeńskiej na stosowanie regulacji prawnych dotyczących zamiany prawa dożywocia na dożywotnią rentę oraz rozwiązania umowy o dożywocie. Problematyka ta, co warto zaznaczyć, obejmuje swym zakresem kwestię oddziaływania nagannego zachowania jednego małżonka na sytuację prawną drugiego małżonka $\mathrm{w}$ ramach stosunku prawnego wynikającego z umowy o dożywocie. Ponadto stan literatury oraz orzecznictwa sądowego jest w tym zakresie niewielki w porównaniu z problematyką odwołania darowizny badaną z tej samej perspektywy. Dlatego też w niniejszym artykule warto przedstawić propozycje rozwiązania pewnych zagadnień szczegółowych, pojawiających się na tle stosowania przepisów dotyczących umowy o dożywocie zawartej przez małżonków pomiędzy którymi istnieje ustawowa wspólność majątkowa małżeńska. Przedmiotem badań są zatem skutki wyroku sądu zamieniającego wszystkie lub niektóre tylko uprawnienia objęte treścią prawa dożywocia, a także wyroku sądu rozwiązującego umowę o dożywocie, przy uwzględnieniu reguł wspólności majątkowej małżeńskiej występującej po stronie zbywcy lub nabywcy nieruchomości.

\section{SKUTKI WYROKU SĄDU ZAMIENIAJĄCEGO \\ UPRAWNIENIA OBJĘTE TREŚCIĄ PRAWA DOŻYWOCIA NA DOŻYWOTNIĄ RENTĘ}

Zamiana prawa dożywocia na dożywotnią rentę może wystąpić w dwóch przypadkach. Po pierwsze, gdy z jakichkolwiek powodów wytworzą się między dożywotnikiem a zobowiązanym takie stosunki, przez które nie można wymagać od stron, aby pozostawały nadal w bezpośredniej ze sobą styczności (art. $913 \S 1$ k.c.). Po drugie zaś, gdy zobowiązany z tytułu umowy o dożywocie zbył nieruchomość, uzyskaną na podstawie umowy o dożywocie (art. 914 k.c.).

Wyrok sądu zamieniający dotychczasowe świadczenia z prawa dożywocia na dożywotnią rentę wywołuje skutki ex nunc, mając charakter konstytutywny².

${ }^{2}$ L. STECKI, Komentarz do art. 913 k.c., [w:] Kodeks cywilny z komentarzem. Tom II, red. J. Winiarz, Warszawa: Wydawnictwo Prawnicze 1989, s. 821; Z. RADwAŃski, Rozdział XIII. Dożywocie, [w:] System Prawa Prywatnego. Prawo zobowiazań - część szczegółowa. Tom 8, red. J. PanowiczLipska, Warszawa: C.H. Beck 2011, s. 765; T. BielskA-Sobkowicz, Komentarz do art. 913 k.c., [w:] Kodeks cywilny. Komentarz. Zobowiązania III, cz. 2, red. J. Gudowski, Warszawa: Wolters Kluwer 2013, s. 1181; K. MularsKi, Komentarz do art. 913 k.c., [w:] Kodeks cywilny. Tom III. Komentarz. Art. 627-1088, red. M. Gutowski, Legalis/el. 2019, nb. 18; J. KuźмicKa-SulikowsKa, Renta dla uprawnionego z tytulu umowy o dożywocie, [w:] Renta w prawie polskim, red. M. Drela, Wrocław: E-Wydawnictwo. Prawnicza i Ekonomiczna Biblioteka Cyfrowa 2016, s. 167; W. Hans, Dożywocie w nowym Kodeksie cywilnym, „Nowe Prawo” 4 (1965), s. 379; uchwała Sądu Najwyższego z dnia 
Pierwszą kwestią sporną jest wpływ powyższego wyroku na istnienie pierwotnego stosunku prawnego wynikającego z umowy o dożywocie. Zgodnie z przeważającym poglądem zamiana części lub wszystkich uprawnień objętych treścią prawa dożywocia powoduje wyłącznie zmianę treści dotychczasowego stosunku prawnego wynikającego z umowy o dożywocie, nie zaś jego wygaśniecie ${ }^{3}$. Pogląd ten należy uznać za słuszny z kilku względów. Przyjęcie, że skutkiem orzeczenia sądu jest przekształcenie prawa dożywocia na dożywotnią rentę kształtuje niezwykle niekorzystnie sytuację prawną dotychczasowego dożywotnika, którego wzmożona ochrona leży u podstaw rozszerzonej skuteczności prawa dożywocia (art. 910 k.c.) oraz roszczeń wskazanych w art. 913 k.c. oraz art. 914 k.c. Należy zauważyć, że wygaśnięcie prawa dożywocia oznaczałoby ustanie obciążenia nieruchomości tym prawem, a co za tym idzie ustaniem rozszerzonej skuteczności prawa dożywocia wobec każdoczesnego właściciela nieruchomości, a także dalszej odpowiedzialności rzeczowej każdego kolejnego nabywcy obciążonej nieruchomości. Po drugie, ustałaby odpowiedzialność osobista zobowiązanego z umowy o dożywocie na podstawie art. $910 \S 2$ k.c. Ponadto dożywotnik zostałby pozbawiony możliwości wystąpienia z żądaniem rozwiązania umowy o dożywocie na podstawie art. 913 $\S 2$ k.c. w sytuacji wystąpienia wyjątkowych okoliczności.

Z powyższych względów należy przyjąć, że wyrok sądu zamieniający wszystkie lub niektóre tylko uprawnienia objęte treścią prawa dożywocia wyłącznie modyfikuje treść stosunku prawnego dożywocia w zakresie przedmiotu świadczenia poprzez zmianę formy zaspokojenia uprawnień dożywotnika. Oznacza to, że do tak ustanowionej dożywotniej renty zamiennej mają zastosowanie przepisy dotyczące umowy o dożywociu, a w szczególności art. 910-912 k.c. ${ }^{4}$

25 lutego 1987 r., sygn. akt III CZP 102/86, „Orzecznictwo Sądu Najwyższego Izby Cywilnej, Pracy i Ubezpieczeń Społecznych” 1988, nr 4, poz. 45; wyrok Sądu Apelacyjnego w Białymstoku z dnia 23 października 2015 r., sygn. akt I ACa 527/15, Legalis nr 1360648.

${ }^{3}$ Radwański, Rozdzial XIII, s. 765, A. OHANowicz, Rozdział XXXVIII. Renta i Dożywocie, [w:] A. Ohanowicz, J. GóRski, Zarys prawa zobowiazań, Warszawa: Wydawnictwo Naukowe PWN 1970, s. 510; B. Lackoroński, Komentarz do art. 913 k.c., [w:] Kodeks cywilny. Komentarz, red. K. Osajda, Legalis/el. 2019, pkt 7; TENŻE, Analiza praktyki sadowej w sprawach z umów renty i dożywocia, Warszawa: Instytut Wymiaru Sprawiedliwości 2015, s. 128, 140; KuźMICKA-SuLIKowsKA, Renta, s. 167-168; wyrok Sądu Apelacyjnego w Szczecinie z dnia 11 czerwca 2014 r., sygn. akt I ACa 307/14, Legalis nr 1241546.

${ }^{4}$ RADWAŃSKI, Rozdzial XIII, s. 765; A. SYLweSTRZAK, Zamiana uprawnień dożywotnika na rente, „Gdańskie Studia Prawnicze” Zagadnienia nauki prawa. W 40-lecie Wydziału Prawa i Administracji Uniwersytetu Gdańskiego 24 (2010), s. 216-217. 


\section{SKUTEK WYROKU SĄDU ROZWIĄZUJĄCEGO UMOWE O DOŻYWOCIE}

Wyrok sądu rozwiązujący umowę o dożywocie ma charakter kształtujący (konstytutywny) ze skutkiem ex nunc, podobnie jak wyrok zamieniający uprawnienia objęte treścią prawa dożywocia na dożywotnią rentę. Jest to bezsporne zarówno w nauce, jak i orzecznictwie sądowym ${ }^{5}$.

Kwestią wywołującą wątpliwości jest natomiast zagadnienie skutku wyroku sądu rozwiązującego umowę o dożywocie w sferze prawnorzeczowej, a zatem w zakresie powrotnego przejścia własności nieruchomości na dożywotnika. Większościowy pogląd zakłada, że wyrok rozwiązujący umowę o dożywocie skutkuje wygaśnięciem prawa dożywocia, a także przeniesieniem własności nieruchomości z powrotem na dożywotnika, będącego zbywcą nieruchomości ${ }^{6}$. Wskazuje się, że z tą chwilą odpada przyczyna prawna, która była podstawą przeniesienia własności nieruchomości przez zbywcę na nabywcę. Podkreśla się przy tym, że przedmiotem rozstrzygnięcia sądu jest jedno roszczenie powoda, a nie oddzielne roszczenia: o rozwiązanie umowy, o wygaśnięcie umowy o dożywocie, oraz o powrotne przeniesienie własności nieruchomości. W konsekwencji niedopuszczalne

${ }^{5}$ RadwaŃSKI, Rozdziat XIII, s. 766; S. DMowski, Komentarz do art. 913 k.c., [w:] G. BIENIEK, H. Ciepla, S. Dmowski [i in.], Komentarz do Kodeksu cywilnego. Ksiega pierwsza. Czesść ogólna, Warszawa: LexisNexis 2011, s. 1014; E. NiezBeCKA, Komentarz do art. 913 k.c., [w:] Kodeks cywilny. Komentarz, red. A. Kidyba, Warszawa: Wolters Kluwer 2010, s. 1241; BielSKA-SobKowicz, Komentarz do art. 913 k.c., s. 1186; G. SiKorski, Komentarz do art. 913 k.c., [w:] Kodeks cywilny. Komentarz, red. J. Ciszewski, Warszawa: LexisNexis 2014, s. 1489; MulaRSKI, Komentarz do art. 913 k.c., nb. 31; LACKOROŃsKi, Komentarz do art. 913 k.c., pkt 13; uchwała Sądu Najwyższego z dnia 8 maja 1975 r., sygn. akt III CZP 31/75, „Orzecznictwo Sądu Najwyższego Izby Cywilnej, Pracy i Ubezpieczeń Społecznych" 1976, nr 2, poz. 32; wyrok Sądu Najwyższego z dnia 17 marca 2004 r., sygn. akt II CK 91/03, „Orzecznictwo Sądu Najwyższego Izba Cywilna” 2005, nr 3, poz. 52.

${ }^{6}$ Zob. z orzecznictwa: uchwała Sądu Najwyższego z dnia 4 lipca 1997 r., sygn. akt III CZP 31/97, „Orzecznictwo Sądu Najwyższego Izba Cywilna” 1998, nr 1, poz. 2; wyrok Sądu Najwyższego z dnia 28 maja 1973 r., sygn. akt III CRN 118/73, „Orzecznictwo Sądu Najwyższego Izby Cywilnej, Pracy i Ubezpieczeń Społecznych” 1974, nr 5, poz. 93; wyrok Sądu Najwyższego z dnia 28 stycznia 1999 r., sygn. akt III CKN 324/98, Legalis nr 357249; wyrok Sądu Najwyższego z dnia 17 marca 2004 r., sygn. akt II CK 91/03, „Orzecznictwo Sądu Najwyższego Izba Cywilna” 2005, nr 3, poz. 52. Zob. z literatury: BielsKa-SoвKowicz, Komentarz do art. 913 k.c., s. 1186; DмоwsKi, Komentarz do art. 913 k.c., s. 1014; NieZBeCKA, Komentarz do art. 913 k.c., s. 1242; SiKorSKi, Komentarz do art. 913 k.c., s. 1489; J. Jeziono, Komentarz do art. 913 k.c., [w:] Kodeks cywilny. Komentarz, red. E. Gniewek, P. Machnikowski, Legalis/el. 2017, nb. 15; RADwAŃski, Rozdziat XIII, s. 769; Z. Policzkiewicz-ZawadzKa, Umowa o dożywocie, Warszawa: Wydawnictwo Prawnicze 1971, s. 131. Zob. również w zakresie rozwiązania umowy o przekazanie gospodarstwa rolnego następcy uchwała Sądu Najwyższego z dnia 5 maja 1993 r., sygn. akt III CZP 9/93, „Orzecznictwo Sądu Najwyższego Izby Cywilnej, Pracy i Ubezpieczeń Społecznych” 1993, nr 12, poz. 215. 
jest uwzględnienie bądź oddalenie takiego żądania jedynie w części ${ }^{7}$. Zauważa się również, że art. 913 § 2 k.c., w odróżnieniu od art. 898 k.c., nie zawiera odesłania do stosowania przepisów o bezpodstawnym wzbogaceniu w zakresie zwrotu przedmiotu umowy. Dożywotnik będący zbywcą nieruchomości staje się ponownie właścicielem nieruchomości z chwilą uprawomocnienia się wyroku sądu o rozwiązaniu umowy o dożywocie ${ }^{8}$. Pogląd ten można nazwać koncepcją rzeczowego skutku rozwiązania umowy o dożywocie.

Właściwy wydaje się jednak drugi, mniejszościowy pogląd, wedle którego wyrok sądu rozwiązujący umowę o dożywocie wywołuje skutki jedynie obligacyjne, w postaci powstania zobowiązania do przeniesienia własności nieruchomości na dożywotnika ${ }^{9}$. Niekiedy w ramach argumentacji za przyjęciem tego poglądu wskazuje się na podobieństwo rozwiązania umowy o dożywocie do odstąpienia od umowy $^{10}$. Odnosząc się do powyższego argumentu, warto zaznaczyć, że rozwiązanie umowy o dożywocie wykazuje podobieństwo nie tylko do odstąpienia od umowy, ale także do odwołania darowizny. Mianowicie, we wszystkich wskazanych wyżej sytuacjach występuje uprawnienie kształtujące stron stosunku prawnego, którego celem jest ustanie tego stosunku. Szczególny charakter wykazuje uprawnienie kształtujące występujące na gruncie umowy o dożywocie, z uwagi na fakt, że jego wykonywanie poddane jest kontroli sądu. We wskazanych przypadkach inne jest zdarzenie prawne prowadzące do ustania istniejącego stosunku prawnego, ponieważ rozwiązanie umowy o dożywocie następuje na mocy prawomocnego wyroku sądu, natomiast odwołanie darowizny oraz odstąpienie od umowy na podstawie złożonego przez stronę oświadczenia woli.

Za przyjęciem obligacyjnego skutku wyroku rozwiązującego umowę o dożywocie przemawiają przepisy dotyczące bezpodstawnego wzbogacenia. Należy bowiem zauważyć, że mają one zastosowanie do stosunku prawnego wynikającego $\mathrm{z}$ umowy o dożywocie, pomimo braku odpowiedniego odesłania $\mathrm{w}$ tym zakresie. Bezpodstawne wzbogacenie jest bowiem instytucją o charakterze ogólnym, a zatem ma zastosowanie do rozliczeń stron, gdy brak jest $\mathrm{w}$ tym zakresie regulacji szczególnej. Jeśli zatem w przepisach regulujących umowę o dożywocie brak jest

\footnotetext{
${ }^{7}$ Wyrok Sądu Najwyższego z dnia 28 maja 1973 r., sygn. akt III CRN 118/73, „Orzecznictwo Sądu Najwyższego Izby Cywilnej, Pracy i Ubezpieczeń Społecznych” 1974, nr 5, poz. 93.

${ }^{8}$ RADWAŃSKI, Rozdziat XIII, s. 769.

${ }^{9}$ LaCKOROŃSKI, Komentarz do art. 913 k.c., pkt 12; Tenże, Analiza, s. 135-136; STECKI, Komentarz do art. 913 k.c., s. 822; S. Rejman, Komentarz do art. 913 k.c., [w:] Kodeks cywilny. Komentarz, tom 2, red. Z. Resich, Warszawa: Wydawnictwo Prawnicze 1972, s. 1766; wyrok Sądu Apelacyjnego w Katowicach z dnia 21 listopada 1995 r., sygn. akt I ACr 520/95, „Orzecznictwo Sądów Apelacyjnych” 1998, nr 3, poz. 11, s. 38 .

${ }^{10}$ LACKOROŃSKI, Analiza, s. 135-136.
} 
regulacji dotyczącej rozliczeń stron, należy przyjąć, że mają do niej zastosowanie przepisy art. 405 n. k.c. Ponadto przy rozliczeniu umowy o dożywocie również mogą wystąpić okoliczności, które znacznie utrudnią lub wręcz uniemożliwią rozliczenie stron in natura, co będzie uzasadniało zwrot wartości korzyści w miejsce jej wydania w naturze. Dotyczy to między innymi przypadku rozporządzenia nieruchomością obciążoną prawem dożywocia przez zobowiązanego. Obligacyjny skutek wyroku rozwiązującego umowę o dożywocie jest tożsamy ze skutkiem zawarcia przez strony umowy rozwiązującej (contrarius consensus), który polega na zobowiązaniu do powrotnego przeniesienia własności na zbywcę ${ }^{11}$. Przyjęty pogląd pełniej realizuje postulat sprawiedliwości kontraktowej, ponieważ uwzględnia interesy obu stron i okoliczności natury faktycznej wpływające na dopuszczalność powrotnego przeniesienia własności nieruchomości obciążonej prawem dożywocia.

\section{ZAMIANA PRAWA DOŻYWOCIA NA DOŻYWOTNIĄ RENTĘ}

ORAZ ROZWIĄZANIE UMOWY O DOŻYWOCIE

\section{WOBEC JEDNEGO Z MAŁŻONKÓW - NABYWCY NIERUCHOMOŚCI}

Problematyka dopuszczalności oraz skutków zmiany prawa dożywocia na dożywotnią rentę oraz rozwiązania umowy o dożywocie, w której nabywcą nieruchomości są małżonkowie pozostający we wspólności majątkowej małżeńskiej stanowi źródło wielu skomplikowanych kwestii, które jak dotąd nie stały się przedmiotem pogłębionych refleksji doktrynalnych i orzeczniczych. Przyczyną tego jest równoległe istnienie trzech stosunków prawnych: zobowiązaniowego, prawnorzeczowego oraz prawnorodzinnego, a w konsekwencji wpływ zasad rządzących małżeńską wspólnotą ustawową na stosowanie przepisów dotyczących umowy o dożywocie.

W ramach uwag porządkujących w pierwszej kolejności należy wskazać, że nieruchomość nabyta przez oboje małżonków na podstawie umowy o dożywocie objęta jest wspólnością majątkową małżeńską (art. $31 \S 1$ k.r.o.). Natomiast na nabycie nieruchomości przez jednego z małżonków w zamian za obowiązek dożywotnich świadczeń niezbędna jest zgoda drugiego małżonka ${ }^{12}$ (art. $37 \S 1$ pkt 1 k.r.o.). Zgoda ta nie jest wymagana jedynie w sytuacji, gdy świadczenie dożywotniego utrzymania będzie spełniane $\mathrm{z}$ majątku osobistego jednego małżonka

${ }^{11}$ Zob. szerzej A. PyrzyŃskA, Rozwiązanie umowy przez strony, Warszawa: C.H. Beck 2000, s. $115 \mathrm{n}$.

${ }^{12}$ S. MadaJ, Umowy o dożywocie pod rzadem Kodeksu cywilnego, „Nowe Prawo” 3 (1966), s. 334; A. Maziarz, Umowa dożywocia jako podstawa wpisu do księgi wieczystej, „Rejent” 2 (2013), s. 104; uchwała Sądu Najwyższego z dnia 18 września 1989 r., sygn. akt III CZP 80/89, „Orzecznictwo Sądów Polskich” 1990, nr 10, poz. 357. 
i wówczas nieruchomość będzie stanowiła majątek osobisty małżonka, będącego stroną umowy (art. 33 pkt 10 k.r.o.).

Niewątpliwie dopuszczalna jest zamiana prawa dożywocia na dożywotnią rentę oraz rozwiązanie umowy o dożywocie wobec obojga małżonków, jeśli odpowiednio przesłanka wystąpienia stosunków, które uniemożliwiają bezpośrednią styczność stron oraz wyjątkowy wypadek, dotyczą ich obojga. Natomiast wątpliwości budzi ich dopuszczalność wobec jednego z małżonków, będącego wraz z drugim małżonkiem nabywcą nieruchomości.

Rozważania w zakresie dopuszczalności omawianych uprawnień co do jednego z małżonków-nabywców nieruchomości należy rozpocząć od charakteru tych uprawnień oraz właściwości (natury) zobowiązania nabywcy nieruchomości wynikającego z umowy o dożywocie. Uprawnienia do zamiany prawa dożywocia na dożywotnią rentę oraz rozwiązania umowy o dożywocie mają charakter indywidualny i osobisty, zaś do właściwości (natury) zobowiązania wynikającego z umowy o dożywocie należy jego alimentacyjny charakter oraz ścisły związek z osobą dożywotnika. Realizacji omawianych uprawnień wobec jednego z małżonków-nabywców nieruchomości nie przeciwstawia się również fakt objęcia nieruchomości obciążonej prawem dożywocia majątkiem wspólnym małżonków. Należy bowiem zauważyć, że art. 913 k.c. nie zawiera żadnych ograniczeń podmiotowych i przedmiotowych w tym zakresie. Nie bez znaczenia są również argumenty natury słusznościowej, których podłożem jest szczególna ochrona dożywotnika, mająca swe odzwierciedlenie w przepisach regulujących umowę o dożywocie. Wskazać należy, że przyjęcie poglądu, wedle którego dożywotnik jest pozbawiony uprawnienia do zamiany prawa dożywocia na dożywotnią rentę oraz rozwiązania umowy o dożywocie wobec jednego ze zobowiązanych małżonków, szczególnie negatywnie kształtuje jego sytuację. Dożywotnik musi bowiem dalej znosić negatywne relacje stron uniemożliwiające dalsze współżycie osobiste stron, zwłaszcza gdy relacje te mają wyjątkowo naganny charakter.

Powyżej zaprezentowane argumenty uzasadniają przyjęcie reguły indywidualizacji podmiotowej przesłanki zamiany prawa dożywocia na dożywotnią rentę oraz rozwiązania umowy o dożywocie również w przypadku, gdy nabywcami nieruchomościami są małżonkowie pozostający w ustroju wspólności majątkowej małżeńskiej. Innymi słowy, omawiane uprawnienia istnieją bez względu na występujące konfiguracje podmiotowe. Jeśli negatywny stan relacji, w tym mieszczący się w zakresie „wyjątkowego wypadku”, istnieje między dożywotnikiem a jedynie jednym z małżonków-nabywców nieruchomości, zamiana prawa dożywocia na rentę oraz rozwiązanie umowy może dotyczyć tylko tego małżonka. Podobny pogląd 
zaprezentował Sąd Najwyższy ${ }^{13}$, uznając za dopuszczalne rozwiązanie umowy $\mathrm{z}$ jednym tylko ze zobowiązanych $\mathrm{z}$ umowy dożywocia, jeżeli tylko w stosunku do niego zachodzą przesłanki rozwiązania umowy ${ }^{14}$.

W odniesieniu do rozwiązania umowy o dożywocie należy rozważyć, czy fakt wejścia przedmiotu umowy do majątku wspólnego małżonków uniemożliwia sformułowanie żądania powrotnego przeniesienia własności (udziału w prawie) nieruchomości na rzecz dożywotnika - zbywcy nieruchomości.

W celu rozstrzygnięcia powyższej kwestii niezbędne jest przyjęcie wstępnego założenia o obligacyjnym skutku rozwiązania umowy o dożywocie. W zgodzie z tym założeniem, należy konsekwentnie stwierdzić, że orzeczenie sądu o rozwiązaniu umowy o dożywocie nie skutkuje ani ustaniem wspólności łącznej co do przedmiotu umowy o dożywocie, ani powstaniem w jej miejsce współwłasności w częściach ułamkowych. De lege lata nie istnieje jakakolwiek podstawa prawna, która uzasadniałaby przyjęcie rzeczowego skutku orzeczenia sądu rozwiązującego umowę o dożywocie, w szczególności przekształcenia dotychczas istniejącego stosunku wspólności łącznej w stosunek wspólności w częściach ułamkowych co do prawa własności nieruchomości, będącej przedmiotem tej umowy.

Należy przyjąć, że konsekwencją rozwiązania umowy o dożywocie wobec jednego z małżonków-nabywców nieruchomości jest obowiązek rozliczenia zgodnie z przepisami o bezpodstawnym wzbogaceniu (art. 405 k.c.). Przy czym ze względu na fakt, że nieruchomość obciążona prawem dożywocia objęta jest wspólnością ustawową, wykluczony jest jej zwrot w naturze w postaci powrotnego przeniesienia udziału w prawie własności nieruchomości, bez zgody drugiego małżonka, co do którego umowa o dożywocie nie została rozwiązana. W przypadku zaś braku

${ }^{13}$ Uchwała Pełnego Składu Izby Cywilnej Sądu Najwyższego z dnia 28 września 1979 r., sygn. akt III CZP 15/79, „Orzecznictwo Sądu Najwyższego Izby Cywilnej, Pracy i Ubezpieczeń Społecznych” 1980, z. 4, poz. 62; uchwała Sądu Najwyższego z dnia 29 września 1992 r., sygn. akt III CZP 98/92, „Orzecznictwo Sądu Najwyższego Izby Cywilnej, Pracy i Ubezpieczeń Społecznych” 1993, nr 3, poz. 35; wyrok Sądu Najwyższego z dnia 19 listopada 2009 r., sygn. akt IV CSK 236/09, Legalis nr 304047.

${ }^{14} \mathrm{~W}$ konsekwencji po stronie pozwanych małżonków w sprawie z powództwa dożywotnika o rozwiązanie umowy o dożywocie zachodzi współuczestnictwo materialne, ze względu na to, że przedmiot sporu stanowią prawa i obowiązki, które są dla nich wspólne (art. $72 \S 1$ pkt 1 k.p.c.), nie zaś współuczestnictwo konieczne - zob. postanowienie Sądu Najwyższego z dnia 21 marca 1968 r., sygn. akt II CZ 67/68, „Orzecznictwo Sądu Najwyższego Izby Cywilnej, Pracy i Ubezpieczeń Społecznych” 1968, nr 11, poz. 197 wraz z aprobującą glosą S. Rejmana, „Nowe Prawo” 5 (1969), s. 832 835; uchwała Sądu Najwyższego z dnia 21 kwietnia 2004 r., sygn. akt III CZP 15/04, „Orzecznictwo Sądu Najwyższego Izba Cywilna” 2005, nr 6, poz. 102; wyrok Sądu Najwyższego z dnia 19 listopada 2009 r., sygn. akt IV CSK 236/09, Legalis nr 304047; BiELSKA-SoBKowiCz, Komentarz do art. 913 k.c., s. 1185; NieZBECKA, Komentarz do art. 913 k.c., s. 1239; MularSKI, Komentarz do art. 913 k.c., nb. 27. 
takiej zgody, istnieje obowiązek zwrotu wartości uzyskanej korzyści, ze względu na brak możliwości zwrotu wartości in natura.

\section{ZAMIANA PRAWA DOŻYWOCIA NA DOŻYWOTNIĄ RENTĘ ORAZ ROZWIĄZANIE UMOWY O DOŻYWOCIE WOBEC JEDNEGO Z MAŁŻONKÓW - ZBYWCY NIERUCHOMOŚCI}

Prawo dożywocia ustanowione na rzecz kilku osób, bez względu na to, czy zbyta nieruchomość stanowiła własność jednej osoby czy też była przedmiotem współwłasności, w tym również w ramach wspólności majątkowej małżeńskiej, nazywane jest w literaturze dożywociem wspólnym ${ }^{15}$. Dopuszczalność ustanowienia dożywocia wspólnego jest niekwestionowana ze względu na treść przepisu art. 911 k.c., zgodnie z którym ,prawo dożywocia ustanowione na rzecz kilku osób ulega $\mathrm{w}$ razie śmierci jednej $\mathrm{z}$ tych osób odpowiedniemu zmniejszeniu".

Należy zauważyć, że nabyte przez małżonków w zamian za przeniesienie własności nieruchomości prawo dożywocia stanowi majątek osobisty każdego z małżonków, ponieważ jest to prawo niezbywalne (art. 33 pkt 6 k.r.o.). Każdemu małżonkowi (dożywotnikowi) przysługują indywidualne uprawnienia obejmujące świadczenia do dożywotniego utrzymania. Dla powyższej kwalifikacji nie ma znaczenia fakt, że zbyta na podstawie umowy o dożywocie nieruchomość stanowiła majątek wspólny małżonków.

W przypadku spełnienia przesłanek do zamiany prawa dożywocia na dożywotnią rentę (art. $913 \S 1$ k.c.) oraz rozwiązania umowy o dożywocie (art. $913 \S 2$ k.c.) należy uznać za dopuszczalne modyfikację bądź zakończenie stosunku prawnego wobec jednego z małżonków. Nie zmienia tego fakt, iż nieruchomość będąca przedmiotem umowy o dożywocie należała do majątku wspólnego małżonków, ponieważ na skutek zawarcia umowy o dożywocie ustała wspólność ustawowa co do tej nieruchomości. Podkreślenia wymaga, że w sytuacji wystąpienia z żądaniem zamiany prawa dożywocia na dożywotnią rentę albo rozwiązania umowy o dożywocie tylko przez jednego z małżonków, odpowiednio modyfikacja albo zakończenie stosunku prawnego dotyczy wyłącznie małżonka występującego z żądaniem. Oznacza to, że konsekwencją rozwiązania umowy wobec jednego z małżonków jest zobowiązanie do powrotnego przeniesienia udziału we własności nieruchomości. W przypadku zaś śmierci jednego z małżonków (dożywotników) rozwiązanie umowy o dożywocie może dotyczyć tylko udziału małżonka (dożywotnika) pozostałego przy życiu. W związku z tym spadkobiercy zmarłego doży-

\footnotetext{
${ }^{15}$ Policzkiewicz-Zawadzka, Umowa, s. 80.
} 
wotnika nie powinni uczestniczyć w procesie o rozwiązanie umowy o dożywocie z drugim dożywotnikiem ${ }^{16}$.

\section{PODSUMOWANIE}

Przeprowadzone rozważania stanowią podstawę do przyjęcia, że stosowanie przepisów prawnych regulujących zamianę prawa dożywocia na dożywotnią rentę oraz rozwiązanie umowy o dożywocie wymaga respektowania przepisów Kodeksu rodzinnego i opiekuńczego dotyczących reguł ustroju wspólności majątkowej małżeńskiej, a zwłaszcza stałości i niezmienności majątku wspólnego małżonków. Zaproponowane rozwiązania można ująć w następujące wnioski podsumowujące. Po pierwsze, zamiana uprawnień wynikających z prawa dożywocia na dożywotnią rentę oraz rozwiązanie umowy o dożywocie dopuszczalne są zarówno wobec obojga małżonków, będących zbywcami lub nabywcami nieruchomości, jak również wobec jednego z nich. Po drugie, na skutek wyroku sądu rozwiązującego umowę o dożywocie nie dochodzi do ustania wspólności łącznej co do przedmiotu umowy o dożywocie, a także powstania w jej miejsce współwłasności w częściach ułamkowych. Objęcie wspólnością ustawową nieruchomości, nabytej na podstawie umowy o dożywocie, uniemożliwia powrotne przeniesienie udziału we własności nieruchomości, bez zgody drugiego małżonka, co do którego umowa o dożywocie nie została rozwiązana. W takim przypadku na zobowiązanym ciąży obowiązek zwrotu wartości uzyskanej korzyści, z uwagi na brak możliwości zwrotu in natura. Po trzecie, zamiana prawa dożywocia na dożywotnią rentę oraz rozwiązanie umowy o dożywocie wobec jednego z małżonków - dożywotników skutkuje obowiązkiem powrotnego przeniesienia udziału we własności nieruchomości albo też zwrotu wartości tego udziału.

\section{BIBLIOGRAFIA}

\section{ŹRÓDEA PRAWA}

Ustawa z dnia z 23 kwietnia 1964 r. - Kodeks cywilny, Dz. U. z 2019 r., poz. 1145.

Ustawa z dnia 25 lutego 1964 r. - Kodeks rodzinny i opiekuńczy, Dz. U. z 2019 r., poz. 2086.

16 TAŻ, Glosa do uchwały składu 7 sędziów SN z 16.3 .1970 r., III CZP 112/69, „Orzecznictwo Sądów Polskich i Komisji Arbitrażowych” 1971, z. 3, poz. 53, s. 113. 


\section{ORZECZNICTWO}

Uchwała Sądu Najwyższego z dnia 8 maja 1975 r., sygn. akt III CZP 31/75, „Orzecznictwo Sądu Najwyższego Izby Cywilnej, Pracy i Ubezpieczeń Społecznych” 1976, nr 2, poz. 32.

Uchwała Pełnego Składu Izby Cywilnej Sądu Najwyższego z dnia 28 września 1979 r., sygn. akt III CZP 15/79, „Orzecznictwo Sądu Najwyższego Izby Cywilnej, Pracy i Ubezpieczeń Społecznych” 1980, z. 4, poz. 62.

Uchwała Sądu Najwyższego z dnia 25 lutego 1987 r., sygn. akt III CZP 102/86, „Orzecznictwo Sądu

Najwyższego Izby Cywilnej, Pracy i Ubezpieczeń Społecznych” 1988, nr 4, poz. 45.

Uchwała Sądu Najwyższego z dnia 18 września 1989 r., sygn. akt III CZP 80/89, „Orzecznictwo Sądów Polskich" 1990, nr 10, poz. 357.

Uchwała Sądu Najwyższego z dnia 29 września 1992 r., sygn. akt III CZP 98/92, „Orzecznictwo Sądu Najwyższego Izby Cywilnej, Pracy i Ubezpieczeń Społecznych” 1993, nr 3, poz. 35.

Uchwała Sądu Najwyższego z dnia 5 maja 1993 r., sygn. akt III CZP 9/93, „Orzecznictwo Sądu

Najwyższego Izby Cywilnej, Pracy i Ubezpieczeń Społecznych” 1993, nr 12, poz. 215.

Uchwała Sądu Najwyższego z dnia 4 lipca 1997 r., sygn. akt III CZP 31/97, „Orzecznictwo Sądu

Najwyższego Izba Cywilna" 1998, nr 1, poz. 2.

Uchwała Sądu Najwyższego z dnia 21 kwietnia 2004 r., sygn. akt III CZP 15/04, „Orzecznictwo Sądu Najwyższego Izba Cywilna” 2005, nr 6, poz. 102.

Wyrok Sądu Najwyższego z dnia 28 maja 1973 r., sygn. akt III CRN 118/73, „Orzecznictwo Sądu

Najwyższego Izby Cywilnej, Pracy i Ubezpieczeń Społecznych” 1974, nr 5, poz. 93.

Wyrok Sądu Najwyższego z dnia 28 stycznia 1999 r., sygn. akt III CKN 324/98, Legalis nr 357249. Wyrok Sądu Najwyższego z dnia 17 marca 2004 r., sygn. akt II CK 91/03, „Orzecznictwo Sądu Najwyższego Izba Cywilna” 2005, nr 3, poz. 52.

Wyrok Sądu Najwyższego z dnia 19 listopada 2009 r., sygn. akt IV CSK 236/09, Legalis nr 304047. Postanowienie Sądu Najwyższego z dnia 21 marca 1968 r., sygn. akt II CZ 67/68, „Orzecznictwo Sądu Najwyższego Izby Cywilnej, Pracy i Ubezpieczeń Społecznych” 1968, nr 11, poz. 197.

Wyrok Sądu Apelacyjnego w Katowicach z dnia 21 listopada 1995 r., sygn. akt I ACr 520/95, „Orzecznictwo Sądów Apelacyjnych” 1998, nr 3, poz. 11, s. 38.

Wyrok Sądu Apelacyjnego w Szczecinie z dnia 11 czerwca 2014 r., sygn. akt I ACa 307/14, Legalis nr 1241546.

Wyrok Sądu Apelacyjnego w Białymstoku z dnia 23 października 2015 r., sygn. akt I ACa 527/15, Legalis nr 1360648.

\section{LITERATURA}

BielsKa-Sobkowicz Teresa: Komentarz do art. 913 k.c., [w:] Kodeks cywilny. Komentarz. Zobowiązania III, cz. 2, red. J. Gudowski, Warszawa: Wolters Kluwer 2013, s. 1180-1186.

DMowski Stanisław: Komentarz do art. 913 k.c., [w:] Gerard Bieniek, Helena CiePŁA, Stanisław DMowski [i in.], Komentarz do Kodeksu cywilnego. Księga pierwsza. Część ogólna, Warszawa: LexisNexis 2011, Warszawa: LexisNexis 2011, s. 1009-1014.

Hans Walerian: Dożywocie w nowym Kodeksie cywilnym, Nowe Prawo 4 (1965), s. 376-383.

Jezıoro Julian: Komentarz do art. 913 k.c., [w:] Kodeks cywilny. Komentarz, red. E. Gniewek, P. Machnikowski, Legalis/el. 2017.

KuŹmicKA-SUlikowsKa Joanna: Renta dla uprawnionego z tytułu umowy o dożywocie, [w:] Renta w prawie polskim, red. M. Drela, Wrocław: E-Wydawnictwo. Prawnicza i Ekonomiczna Biblioteka Cyfrowa 2016, s. 153-176. 
LACKOROŃSKi Bogusław: Analiza praktyki sądowej w sprawach z umów renty i dożywocia, Warszawa: Instytut Wymiaru Sprawiedliwości 2015.

LACKOROŃSKi Bogusłw: Komentarz do art. 913 k.c., [w:] Kodeks cywilny. Komentarz, red. K. Osajda, Legalis/el. 2019.

Madaj Stanisław: Umowy o dożywocie pod rządem Kodeksu cywilnego, Nowe Prawo 3 (1966), s. $332-339$.

MaZIarz Agnieszka: Umowa dożywocia jako podstawa wpisu do księgi wieczystej, Rejent 2 (2013), s. $98-108$.

MularsKi Krzysztof: Komentarz do art. 913 k.c., [w:] Kodeks cywilny. Tom III. Komentarz. Art. 627-1088, red. M. Gutowski, Legalis/el. 2019.

NiezBecka Elżbieta: Komentarz do art. 913 k.c., [w:] Kodeks cywilny. Komentarz, red. A. Kidyba, Warszawa: Wolters Kluwer 2010, s. 1235-1242.

OHANowicz Alfred: Rozdział XXXVIII. Renta i Dożywocie, [w:] Alfred OHANOwicz, Józef Górski, Zarys prawa zobowiązań, Warszawa: Wydawnictwo Naukowe PWN 1970, s. 506-512.

Policzkiewicz-ZawadzKa Zofia: Glosa do uchwały składu 7 sędziów SN z 16.3.1970 r., III CZP 112/69, „Orzecznictwo Sądów Polskich i Komisji Arbitrażowych” 1971, z. 3, poz. 53.

Policzkiewicz-Zawadzka Zofia: Umowa o dożywocie, Warszawa: Wydawnictwo Prawnicze 1971. PyrzyŃsKa Agnieszka: Rozwiązanie umowy przez strony, Warszawa: C.H. Beck 2000.

Radwański Zbigniew: Rozdział XIII. Dożywocie, [w:] System Prawa Prywatnego. Prawo zobowiązań - część szczegółowa. Tom 8, red. J. Panowicz-Lipska, Warszawa: C.H. Beck 2011, s. 754-772.

Rejman Stanisław: Komentarz do art. 913 k.c., [w:] Kodeks cywilny. Komentarz, tom 2, red. Z. Resich, Warszawa: Wydawnictwo Prawnicze 1972, s. 1763-1767.

Rejman Stanisław: Glosa do postanowienia Sądu Najwyższego z dnia 21.3.1968 r., II CZ 67/68, Nowe Prawo 5 (1969), s. 832-835.

SiKORSKI Grzegorz: Komentarz do art. 913 k.c., [w:] Kodeks cywilny. Komentarz, red. J. Ciszewski, Warszawa: LexisNexis 2014, s. 1487-1493.

STECKI Leopold: Komentarz do art. 913 k.c., [w:] Kodeks cywilny z komentarzem. Tom II, red. J. Winiarz, Warszawa: Wydawnictwo Prawnicze 1989, s. 820-822.

SylwestrzaK Anna: Zamiana uprawnień dożywotnika na rentę, Gdańskie Studia Prawnicze 24 (2010), s. 13-26.

\section{INNE ŹRÓDŁA}

Sytuacja demograficzna osób starszych i konsekwencje starzenia się ludności Polski w świetle prognozy na lata 2014-2050, Warszawa: Główny Urząd Statystyczny 2014, [w:] https://stat.gov.pl/obszary-tematyczne/ludnosc/ludnosc/sytuacja-demograficzna-osob-starszych-i-konsekwencje-starzenia-sie-lud nosci-polski-w-swietle-prognozy-na-lata-2014-2050,18,1.html [dostęp: 5.06.2019].

\section{UMOWA O DOŻYWOCIE W SFERZE WSPÓLNOŚCI MAJĄTKOWEJ MAŁŻEŃSKIEJ}

\section{Streszczenie}

W niniejszym artykule poddano analizie dopuszczalność zamiany wszystkich lub niektórych uprawnień objętych prawem dożywocia na dożywotnią rentę oraz rozwiązania umowy o dożywocie w sytuacji gdy po stronie zbywców lub nabywców nieruchomości występują małżonkowie pozostający 
we wspólności majątkowej małżeńskiej. Następnie określono skutki wyroku sądu zamieniającego uprawnienia objęte prawem dożywocia na dożywotnią rentę oraz wyroku sądu rozwiązującego umowę o dożywocie i wpływ regulacji Kodeksu rodzinnego i opiekuńczego na stosowanie przepisów Kodeksu cywilnego regulujących umowę o dożywocie.

Słowa kluczowe: dożywocie; rozwiązanie umowy o dożywocie; zamiana prawa dożywocia na dożywotnią rentę; prawo zobowiązań; majątek wspólny małżonków

\section{LIFE ANNUITY CONTRACT IN THE SPHERE OF JOINT PROPERTY REGIME}

\section{Sum mary}

The subject of the analysis of this article is the admissibility of conversion of all or some rights covered by the contents of the right to annuity into a lifetime pension and termination of a life annuity contract where the transferor or acquirer of immovable property are spouses in statutory property regime. Next, the effects of the court judgment changing the rights covered by right to annuity into a lifetime pension and the court judgment terminating the life annuity agreement and the impact of the Family and Guardianship Code regulations on the application of the Civil Code provisions regulating the life annuity contract were determined.

Key words: annuity; termination of life annuity contract; conversion of the life annuity right into a pension for life; contact law; common property of the spouses 